\title{
千里ニュータウン集合住宅団地内に現存する樹木の樹形と立地との関連 \\ A Study of Characteristics of Existing Plants Established in Collective Housing Sites of Senri New Town
}

\author{
篠沢 健太* 宮城 俊作** 根本 哲夫*** 左岦 晋吾* \\ Kenta SHINOZAWA Syunsaku MIYAGI Tetsuo NEMOTO Shingo SAZAKI
}

\begin{abstract}
Through the development process of collective housing sites in Senri New Town, planted areas in residential lots have been established as a component of natural and artificial environment of the area. Facing a challenge of restoring old collective housings, we intended to clarify characteristics of existing arbores in collective housing sites developed by Japan Housing Corporation. Applying data of tree height, branch spread, and trunk circumference, the characteristics of tree figure and its changes were investigated by comparison of arboreal vegetation of two selected sites. Not only layout of buildings and open spaces but also maintenance practice of vegetation critically affected figures and growth of the trees. Among the findings, it was noted that development process, land formation in particular, of housing lot also affected their growth. In terms of decision making on whether to conserve or transplant existing trees in restoration procedure, significance of those trees on the site should be reorganized through evaluation on trees themselves, context of landscape and development process by revealing archival records. Updating the records is also important to inherit the values of open spaces in collective housing sites as natural environmental structure.
\end{abstract}

Keywords: collective housing, existing plants, development of building lots, Senri New Town, Japan Housing Corporation キーワード：集合住宅団地，現存樹木，宅盤整備，千里ニュータウン，日本住宅公団

\section{1. はじめに}

高度経済成長期に開発された集合住宅団地 (以下, 団地と示す) では，住棟間緑地やプレイロットなど居住空間に近接した緑地が 形成され，居住者との密接な関係が指摘されている ${ }^{1)}$ ここうした 団地内緑地は, 多くの場合その存続が公共的に担保されておらず, 住棟建替事業に際して, その保全や更新のあり方が課題となって いる ${ }^{2)}$ 。開発当時植栽された樹木は, 年月を経て, 現在は団地や 地域のシンボルやランドマークとなっており，保全，移植，伐採 等の判断が問われる。通常その判断に際しては, 位置, 樹高など 樹木の物理的な特徵および居住者の意向が尊重され, アンケート 調査などに居住者の嗜好を把握して，愛着のある樹木を保全する ことが検討，実施されている ${ }^{3)}$ 。また建替団地内の樹木を敷地内 に効果的に移植したり，移植が不可能な場合も，その木質資源を 敷地内で再利用する試みが効果を発揮している ${ }^{4)}$ 。

アンケート調査などでは，住民の直接意思が反映される反面， その嗜好が主観的，流動的な場合もあり，人々が樹木の何にどの ような愛着や価值を認めたかを明らかにすることが重要となる。 また樹木を移植する場合には, 植物そのものは生存しつづけるが, 植栽された場所における樹木の履歴やまちの文脈のなかでの経緯, その存在価值についてはあまり議論されない。樹木を残すことを 重視するあまり，保全された樹群が新たに開発された地域のなか で適切に位置づけられず, 空間的, 機能的に孤立することもある。

本論は, 団地内に現存する樹木 (高木) 群を開発計画の過程や 履歴を記録しつつ形成された「緑のストック」ととらえ，それら を現地において保全する意味を明確にすることを目的とした事 例・調査研究である。具体的には，既存の図面資料の収集・分析 に基づいて，(1)現存樹木の基礎的情報から団地内の植栽の特性を 把握した上で，(2)その樹形の特徵と植栽された位置から，団地内 の空間計画やその変遷が植栽計画や樹木の成長に及ぼした影響を 探り，(3)立地との関係から現存樹木のストックとしての存在価值 を明らかにすることを試みた。

\section{2. 対象と方法}

対象として, 現在団地建替事業が進行中で, 現存樹木の価值や 意義の検討が急務である千里ニュータウン（以下ニュータウンを NT と示す）を選んだ。竣工当時から資料が保管され，同時に現存 樹木の情報が入手できた日本住宅公団（現 : UR 都市機構）整備の 団地のうち, 公団千里津雲台団地と公団新千里北町団地の 2 団地 を対象とした（以下，津雲台，北町とする）。津雲台は敷地面積 8. 87ha, 住戸数 1,100 戸，北町は 5.76ha， 730 戸のともに中層賃 貸住宅で，一部改修が行われている。

分析に用いた資料と分析手順は以下の通りである。

\section{（1）平成 15 年度団地植物管理工事図表に基づく分析}

現存樹木のデータとして, 都市基盤整備公団関西支社千里住宅 管理センターが作成した平成 15 年度千里津雲台団地, 新千里北町 団地植物管理工事植栽位置図と植栽表 ${ }^{5}$ をを用いた（以下植物管理 工事図表と記す）を用いた。団地区域内は住棟ごとに区分され， 区域ごとに番号付けされた高・中木と低木·生垣の位置が記され， 樹高, 幹周, 葉張, 面積等が計測されている。今回は樹高, 幹周, 葉張が明らかな高木のみに限定し, 現存樹木の本数や樹種, 樹形 と植栽位置や管理との関係など基礎的な分析を行った。

\section{（2）団地竣工図との比較}

植栽管理図と竣工図を比較して, 竣工時より継続して生育する 樹木を特定し，その特徵を把握した。竣工時の樹木やその規格に ついは全てが明確とはならなかったため, 現存樹木の図面上の 位置と植栽管理図の分析結果から判断した。

\section{（3）日本住宅公団による団地宅盤造成の影響の把握}

千里 NT は, 大阪府企業局が NT 全域の土地基盤造成（粗造成） を行い, さらにその造成地盤を, 各団地開発主体が改変して宅盤 造成（精造成）を行っている。今回，現存樹木のストックとして の存在価值を検討するために, 公団による宅盤造成で生じた切盛 の変化に着目した。府企業局が公団の宅盤整備前に検討した「住 棟配置計画案」 ${ }^{6)} よ り$ 粗造成の状態を把握した結果, (1)府企業局

\footnotetext{
*大阪芸術大学芸術学部 **奈良女子大学 ****株)日建設計
} 


\section{表－1＼cjkstart対象団地の現存樹木(高木)の樹種と本数}

\begin{tabular}{|c|c|c|}
\hline \multicolumn{2}{|c|}{ 千里津雲台 TKM } & (本) \\
\hline 1 & サンゴジュ & 353 \\
\hline & カイズカイブキ & 98 \\
\hline 3 & ケヤキ & 96 \\
\hline & トウネズミモチ & 89 \\
\hline 5 & アラカシ & 68 \\
\hline & シラカシ & 67 \\
\hline & サクラ類 & $65 \%$ \\
\hline & クスノキ & 64 \\
\hline 9 & ピワ & 38 \\
\hline 10 & キンモクセイ & 36 \\
\hline 11 & ムクゲ & 34 \\
\hline & クロガネモチ & 33 \\
\hline 12 & ユリノキ & 33 \\
\hline 14 & トウカエデ & 31 \\
\hline 15 & マテバシイ & 29 \\
\hline 16 & ピラカンサ & 20 \\
\hline 17 & ナンキンハゼ & 19 \\
\hline 18 & ハナミズキ & 18 \\
\hline 19 & サルスベリ & 17 \\
\hline 20 & ヒマラヤシーダー & 16 \\
\hline 20 & メ夕セコイヤ & 16 \\
\hline & ウバメガシ,トベラ & 13 \\
\hline & ウメ,カキ,ツバキ & 12 \\
\hline & カナメモチ,プラタナス & 10 \\
\hline & $ク ゚ ミ$ & 9 \\
\hline & イロ八モミジ,ミカン & 8 \\
\hline & $=L$ & 7 \\
\hline & イチョウ.ケ゚ッケイジュ & 6 \\
\hline & キョウチクトウ,ザクロ,マサキ & 5 \\
\hline & Iノキ & 4 \\
\hline
\end{tabular}

\begin{tabular}{|c|c|c|c|}
\hline \multicolumn{2}{|c|}{ 新千里北町 KITA } & \multicolumn{2}{|c|}{ (本) } \\
\hline & マッ類 & 111 & ※2 \\
\hline & ケヤキ & 102 & \\
\hline 3 & シラカシ & 89 & \\
\hline & クスノキ & 80 & \\
\hline & ヒマラヤシーダー & 51 & \\
\hline 6 & ビワ & 50 & \\
\hline & コナラ & 40 & \\
\hline 8 & ナンキン八セ゚ & 35 & \\
\hline & モミジ & 32 & \\
\hline 10 & サクラ類 & 27 & $\approx 3$ \\
\hline 11 & クヌギ & 22 & \\
\hline 12 & トウカエデ & 21 & \\
\hline 13 & メ夕セコイヤ & 20 & \\
\hline 14 & ミミン & 16 & \\
\hline 15 & タブやキ & 13 & \\
\hline 16 & イチョウ & 9 & \\
\hline 16 & ウx & 9 & \\
\hline 18 & カキ & 8 & \\
\hline 19 & エノキ,エンジュ & 7 & \\
\hline 20 & アキニレ,ヒノキ & 6 & \\
\hline & タイワンフウ,モチノキ,モモ & 5 & \\
\hline & カリン,サルスベリ & 4 & \\
\hline & ザクロ,ハナミズキ & 3 & \\
\hline *1 & 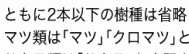 & & \\
\hline
\end{tabular}

の粗造成では原地形や自然植生地が部分的に保全され，(2)公団の 精造成は，粗造成の方針を継承していた ${ }^{6)}$ た，(3)開発前の原地 形と現在の地形の比較では把握できない植栽や樹木の生長への詳 細な影響を,宅盤造成の切盛の変化から把握できるのではないか, と考えたからである。現在の地形と府「住棟配置計画案」の比較 から宅艋造成の切盛の違いを把握し，植栽管理図の資料のうち， 植栽後の剪定など維持管理の影響を受けにくい幹周を植物の生育 の指標として，切土・盛土地で差異があるかを検討した。

\section{3. 結果と考察}

\section{（1）千里 NT 集合住宅団地内の現存樹木}

植物管理工事図表に記載された現存樹木 (高木)の植栽本数は, 津雲台 1, 434 本，北町 811 本，樹種は順に 70 種，44 種であった (表一 1 )。津雲台はサンゴジュが 353 本と最も多く, カイズカイ ブキ 98 本，ケヤキ 96 本と続き，北町はマツ類が 111 本と最多で 次いでケヤキ 102 本, シラカシ 89 本であった。植栽樹種の違いは 千里 NT における開発時期，住区の位置（周辺緑地との関係）や, 立地特性，植栽の意図の違いと考えられる。両団地内に共通して 多く植栽された樹種はケヤキ, クスノキ, シラカシ, サクラ類で あった。またビワ，ウメ，カキなどの果樹が順に 89 本，95 本と， 約 1 割を占めていた。

\section{（2）現存樹木の樹形の特徵}

植物管理工事図表の樹高と枝張から，両団地の現存樹木の樹形 分布（図一 1 ）をみると, 津雲台と北町とも樹高, 枝張 $6 \mathrm{~m}$ 以内の 樹木が多い。樹高 $10 \mathrm{~m}$ を超える樹木をみると，津雲台は樹高区分 に連続して分布し，住棟の高さを超える高木（メタセコイヤ等） が存在するのに対し，北町は樹高分布が $12 ， 15 \mathrm{~m}$ に偏っている。 枝張は津雲台で全体に大きいが，これは北町に比べ津雲台の竣工 時期が早く，歩行者専用道路に沿ったプレイロットに配植された 樹木群が枝を延ばしたためと考えられる。両団地とも中層住棟に 隣接して植栽するため, 樹高, 枝張は剪定など維持管理の影響を 受ける。また植栽時の樹木は規格寸法であることから，植栽時期 や生長の過程も推測できる。例えばシラカシをみると，北町では 樹高 $5 \mathrm{~m}$ 以内の規格寸法の樹形に近いのに対し, 津雲台ではほとん どが $6 \mathrm{~m}$ を超え，定着後の生長が示唆される（図一 2 , 後述)。

上記の検討から，現存樹木が樹高，枝張ともに生長しているの か，剪定等の管理により変形しているのか，あるいは生育不良な のかが示唆される。現存樹木の樹形は, 竣工時の配植や植栽密度,
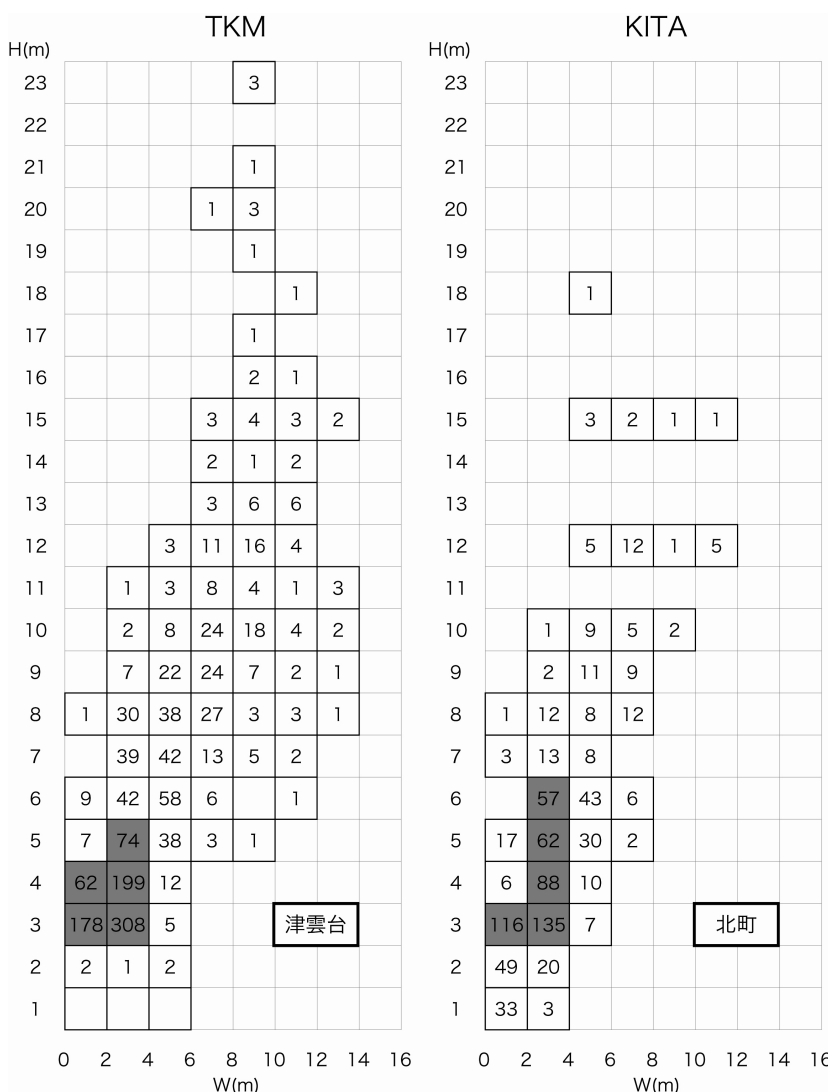

図－1 現存樹木の樹形（編みかけ部分は植栽時の樹形）
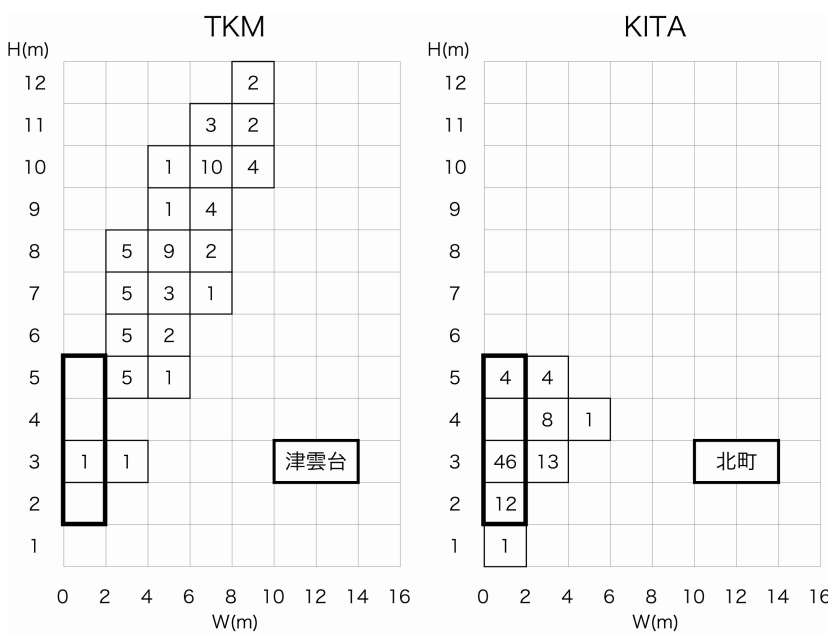

図一2 シラカシの樹形(樹高 $\mathrm{H} \times$ 枝張W, 左; 津雲台, 右; 北町) 太枠は植栽時のシラカシの標準的な規格形状

プレイロットや住棟との距離など団地住棟とオープンスペースの 配置計画，剪定等の経年的な管理の影響などを反映した，独自の 履歴を継承していることが確認された。

\section{（3）竣工当時の植栽木変化}

上記の樹形の特徵を検証するために，竣工図に記載されている 植栽樹木の位置と規格をみた。竣工時の高木植栽は本数，樹種共 に現存樹木よりも少なかった。前述した果樹は，竣工図には記録 されておらず, 竣工後に植栽され, 成長したと考えられる。津雲 台で $6 \mathrm{~m}$ 以上の高木に生長したシラカシは, 竣工時の樹高は $3.5 \mathrm{~m}$ であった。また樹高 3〜 4m 程度の津雲台のサンゴジュ, カイズカ イブキや北町のシラカシなどは, 植栽位置から, 䇋工後, 総合団 地環境整備事業などにより駐車場が新設され，その周囲に新植さ 

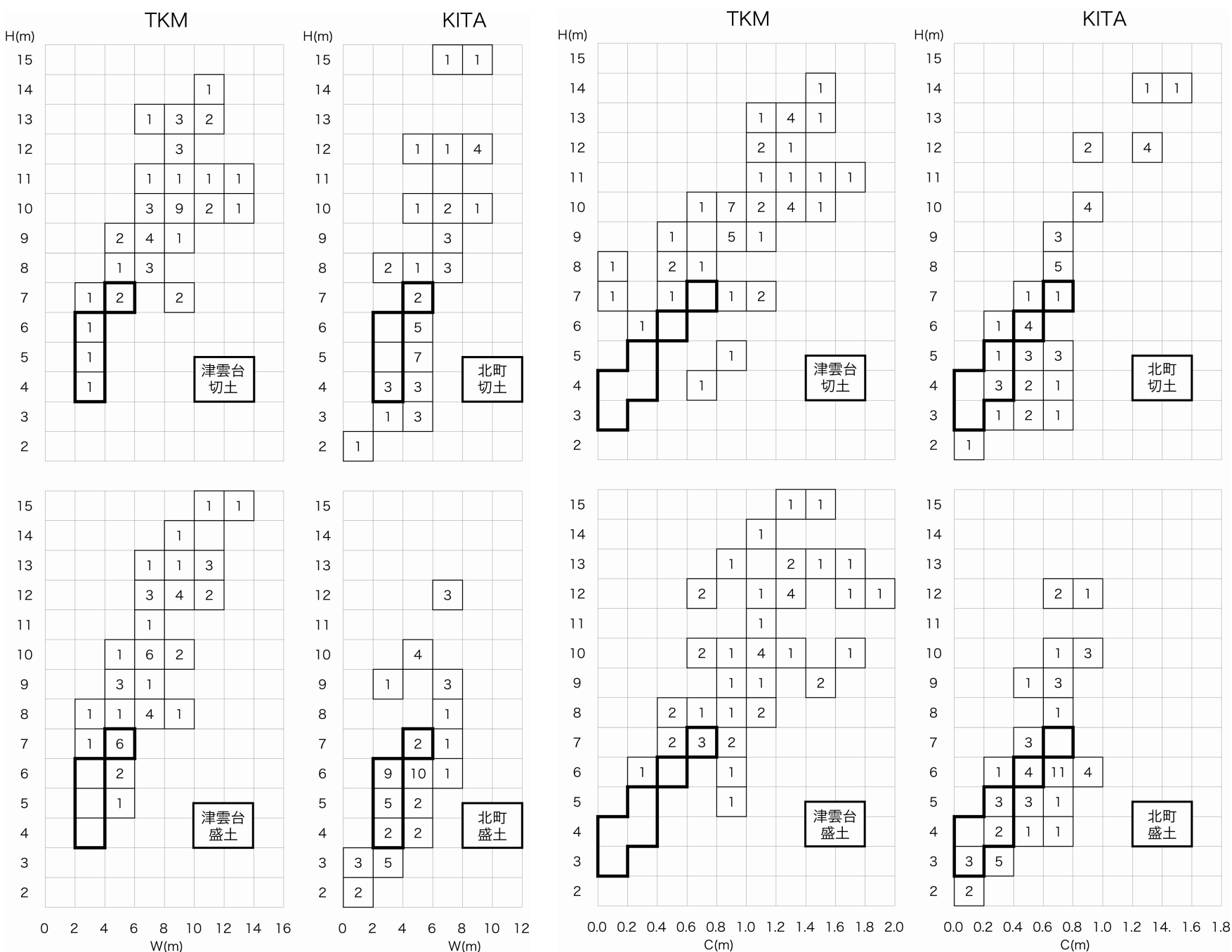

\section{図一3 ケヤキの樹形（樹高 $\mathrm{H} \times$ 枝張W, 左; 津雲台, 右; 北町 太枠は植栽時のケヤキの標準的な規格形状}

れたと考えられる ${ }^{8)}$ 。

\section{（4）団地宅盤造成の現存樹木の生長への影響}

団地宅盤造成の現存樹木一の影響を検討寸るため, 切／盛土地 ごとにケヤキの樹形を比較した (図-3)。津雲台は盛土地, 北町 は切土地で樹高，枝張が大きくなる傾向が見られた。ただし樹高 や枝張などの樹形の特徴は，住棟への近接などの配植状況や剪定 等の維持管理により変化し，樹木の成長を一概に議論できない。

そこでケヤキ，クスノキ，サクラ類の幹周を切／盛土地ごとに 比較した (図一 $4 \sim 6$ )。ケヤキの幹周は北町では切／盛土地の差 は顕著ではない。津雲台では樹高が大きくなるにつれ，盛土地の ケヤキの幹周の分布域が広がる傾向が見られる(図一4)。常緑樹 のクスノキでも津雲台，北町ともに盛土地で幹周が大きくなる傾 向が見られた。規格寸法と比較すると樹高 $7 \mathrm{~m}$ 以下では幹周が規格 を下回り，樹高 $8 \mathrm{~m}$ 以上では津雲台で幹周の分布が分散していた (図一 5 )。通常剪定管理されることが少ないサクラ類は, 切土で 樹高に応じた生長の傾向が見られる。一方，津雲台の盛土では， 幹周の分布に偏りがあった（図一6）。

以上から，盛土地に生育する高木樹木に造成の影響が見られ， 現存樹木の保全・移植の判断の一視点となると思われる。ただし 住棟やオープンスペースの配置計画が地形と関連しているため, 幹周の分布が宅盤造成に起因する生理的影響か，樹木の配植計画 によるものかは安易に決断できない。津雲台では歩行者専用道路, 北町では中心部の児童公園に大径木が分布する傾向がみられた。

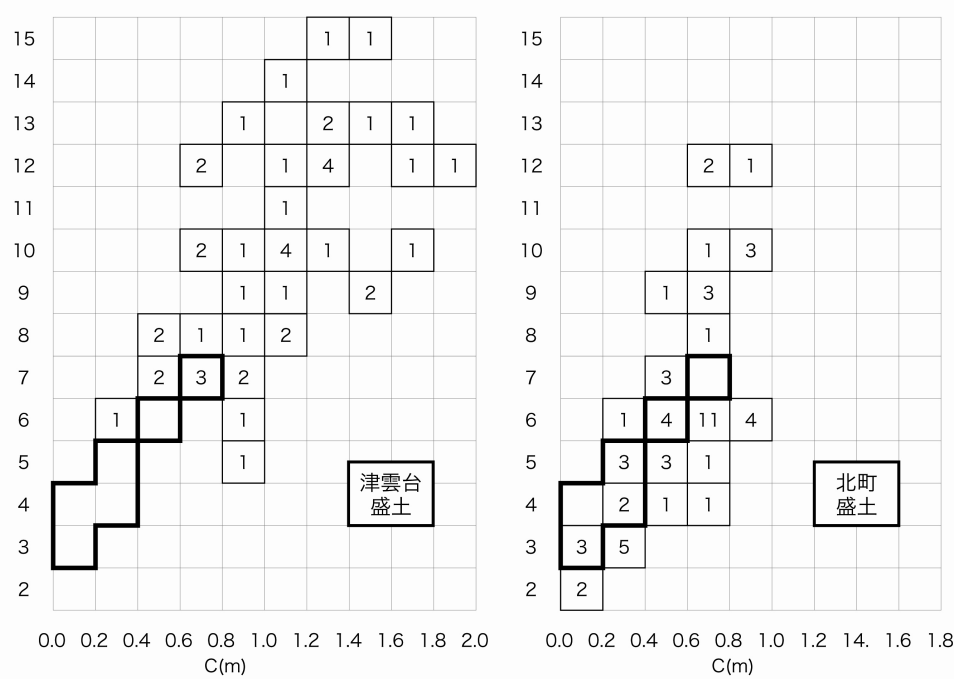

\section{図-4 ケヤキの樹高 $\times$ 幹周と宅盤造成（切／盛）の関係 太枠は植栽時のケヤキの標準的な規格形状}

今回は切／盛土地を区域の違いで比較したが，宅盤造成が植物の 生理生態に与えた影響を詳細に議論するためには，切盛土工深さ や毎木調査など, 詳細な検討が必要となるだろう。

\section{4. まとめ}

本論の検討から団地内に現存寸る樹木は，標準的な規格寸法で 植栽された後, 生長していく変化の過程を通じて, 開発の経緯や 履歴を反映した特徴を有していることが明らかになった。団地内 の樹木の樹形は，住棟との距離やオープンスペースとの近接状態 など配置計画や，配植位置や剪定など維持管理の違い，竣工後の 駐車場整備など団地内の空間計画の履歴を反映し，樹種ごとに異 なる特性をもっていた。さらに一見均質に見える宅盤も原地形や 開発過程の違いにより異なる立地条件をもち，ある種の樹木には その違いが反映される可能性も示唆された。このことは現存樹木 がまちの「文脈」の記録し，それらを適切に把握・分析すること によって立地の特性を読み解くことができることを意味している。 団地内で生育した現存樹木を緑のストックとして継承する上で, 現地保存が重要であることを意味している。今後集合住宅団地の 建替事業や地域再開発に際して, 団地内の現存樹木を現地で保全 することが，新たに創出されるランドスケープ計画が地域の自然 環境構造を保全・補完する上で重要な資産となるが，本論はその 手法の糸口を示したにすぎず，ストックとしての客観的な評価， 判断については今後の課題としたい。 

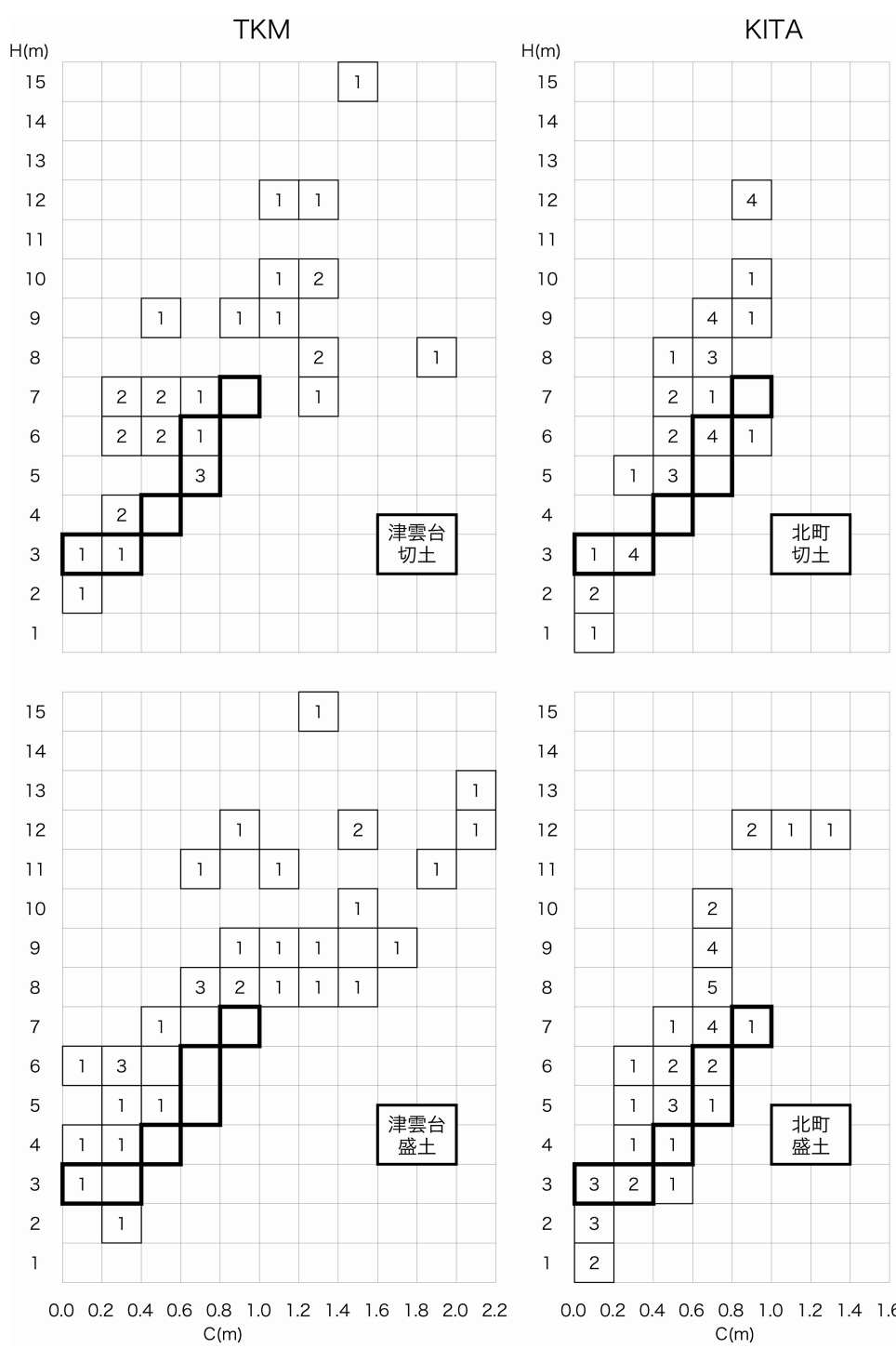

\section{図一 5 クスノキの樹高 $\times$ 幹周と宅盤造成（切／盛）の関係 太枠は植栽時のクスノキの標準的な規格形状}

一方，本論では竣工時，計画過程，および現存樹木に関する情報 が入手しやすい団地を対象としたが，竣工時の資料が紛失，散逸 し，現存樹木の状況が適切に把握されていないことも多い。現存 樹木の本来の意義を明らかにするためには，残された情報資料を 収集・整理したうえで，両者を統合するアーカイブを構築するこ とが重要となると考える。

謝辞:

緑環境チームの山本幹雄さまには資料提供にご尽力いただいた。 ここに記して感謝の意を表します。本研究は独立行政法人日本学 術振興会平成 21-23 年度科学研究費基盤研究 (C) 課題番号 21580032 「自然環境構造の顕在化をめざすランドスケープ計画・ 設計モデルの構築」（研究代表者 : 宮城俊作）に基づいている。

\section{補注及び引用文献}

1）竹原祐介・高田光雄（1997）: 環境形成的視点から見た公団住宅の建替 えに関する研究 : 戻り入居者の住環境評価と建替えの合意形成の関係に つて : 日本建築学会計画形論文集(496)，81-88.

2）篠沢健太・宮城俊作(2004) : 集合住宅団地内緑地の“ストック”としての 再評価 : ランドスケープ研究 68(1), 28-31
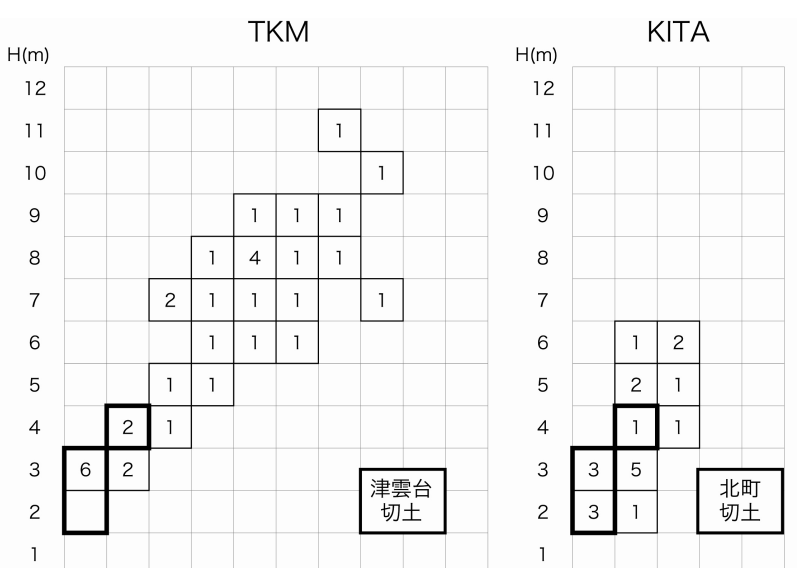

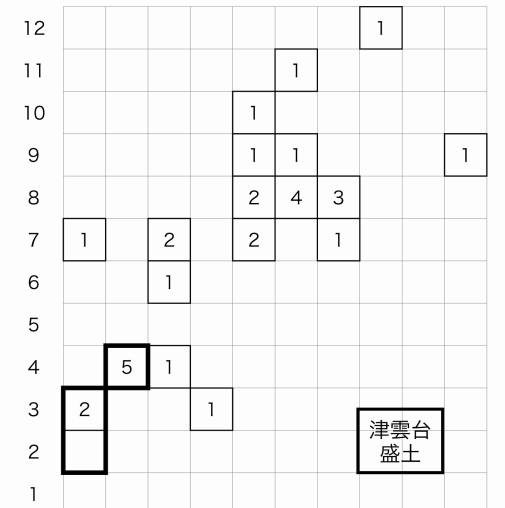

$\begin{array}{llllllllllllll}0.0 & 0.2 & 0.4 & 0.6 & 0.8 & 1.0 & 1.2 & 1.4 & 1.6 & 1.8 & 2.0\end{array}$ $\mathrm{C}(\mathrm{m})$

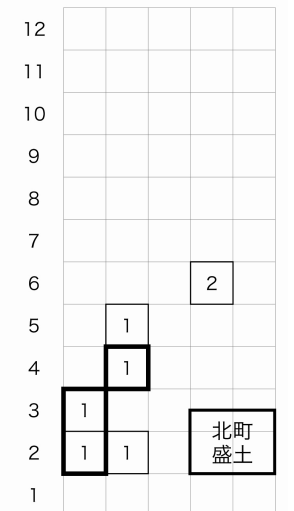

$\begin{array}{llllll}0.0 & 0.2 & 0.4 & 0.6 & 0.8 & 1.0\end{array}$ $\mathrm{C}(\mathrm{m})$

\section{図一6 サクラ類の樹高 $\times$ 幹周と宅盤造成（切 $/$ 盛）の関係 太枠は植栽時のサクラ類の標準的な規格形状}

3）加我宏之ほか (2003) : 既存樹木が保存された建替団地における建替前 後の団地空間に対する居住者の嗜好性の変容に関する研究 : ランドスケー プ研究 67(5), 697-702.

4）小木曽裕(2005) : 立て替え団地における既存樹木里活用に対寸る居住者 意識. ランドスケープ研究 68(5), 769-772.

5）都市基般整備公団関西支社千里住宅管理センター (2003) : 平成 15 年 度千里津雲台団地, 新千里北町団地植物管理工事植栽位置図, 植栽表. 植物管理の基礎資料として，団地内すべての樹木が毎木調查され，位置 と樹種を記録した図面と，種名，樹高，枝張，幹周等を記録したリスト が作成されている。経年変化した幹周の調查や枯損木，新植樹木の修正 が約 5 年周期に行われている。

6) 大阪府企業局が作成した住棟配置計画案は, 当時の企業局担当者が作成 した「宅造レイアウトパターン集」として $25 \mathrm{~cm}$ 四方の $1: 1,000$ 青焼図 として整理されている。詳細は, 篠沢健太, 宮城俊作, 根本哲夫 (2010)： 千里ニュータウンの集合住宅団地に内在する自然環境の構造とその形成 過程. ランドスケープ研究 : 73(5)，731-736.を参照のこと。

7）日本住宅公団の宅盤整備では, 府企業局が切土造成した地盤を再度盛士 したり，逆に盛十造成した地盤を切土寸ることはほとんどなかった。

8）住宅・都市整備公団関西支社（1991）: 千里津雲台団地駐車場基盤整備 工事 (第 1 次～第 3 次). 図面番号 1544-223 274，1548-100 138. 